\section{Physicists in Britain during July}

The Eighth General Assembly of the International Union of Pure and Applied Physics will be held in London during July 7-10 in the rooms of the Royal Society. The business meetings will be attended by delegates from the national adhering organizations of the International Union and by members of the Union's Commissions on Publications and Symbols, Units and Nomenclature ; but, in order to profit by the fact that a number of distinguished foreign scientists will be in Britain for the occasion, a number of conferences on physical subjects have been arranged. Under the auspices of the International Union, two conferences will be held during July 1317 : one in Glasgow on experimental and theoretical nuclear physics, under the chairmanship of Prof. P. I. Dee, at which problems of nuclear structure and properties of mesons will be dealt with; and the other in Bristol on the physics of the solid state, under the chairmanship of Prof. N. F. Mott, at which defects in crystalline solids, and particularly their investigation by the use of microwaves and the relation between dislocations and other defects, will for the most part be considered. During the General Assembly of the Union, three lectures arranged by the Physical Society will be given at the Royal Institution by Profs. J. A. Wheeler, E. Amaldi and Charles Kittel on July 7 and 9 (at 4.30 p.m.) and July 12 (2.30 p.m.), respectively. In addition to these events, a small limited meeting on the mechanical properties of metals will be held during July 19-20 in the Department of Metallurgy of the University of Birmingham under the chairmanship of Prof. M. Cottrell, and the International Commission on Electron Microscopy will be holding a meeting in London during July 16-21.

\section{Chemical Society: Anniversary Meetings in Man- chester}

THE anniversary meetings of the Chemical Society will be held this year in the University of Manchester during March 31-April 2. The proceedings will commence with a symposium on "Dynamic Stereochemistry", arranged jointly with the Manchester Sections of the Royal Institute of Chemistry, the Society of Chemical Industry and the Institute of Petroleum. It is hoped that the speakers will include Prof. C. K. Ingold, Prof. E. D. Hughes, Dr. P. B. D. de la Mare, Prof. E. Winstein (Los Angeles, California), Prof. V. Prelog (Zurich), Prof. D. H. R. Barton and Prof. K. Alder (Cologne). Further details of this symposium can be obtained from Dr. M. A. T. Rogers, Academic Relations Department, Imperial Chemical Industries, Ltd., Dyestuffs Division, Hexagon House, Blackley, Manchester 9. On the following day, April 1, there will be the annual meeting of local representatives of the Society, followed at 11.30 a.m. by the Liversidge Lecture, to be given by Prof. H. J. Emeléus, professor of inorganic chemistry in the University of Cambridge, who will speak on "Organometallic Compounds containing Fluorocarbon Radicals". On April 2 the Society will hold its annual general meeting, and then at 11 a.m. the president, Prof. C. K. Ingold, professor of chemistry in University College, London, will give the presidential address. The afternoons of April 1 and 2 will be devoted to visits to industrial organizations, and all three evenings will be taken up with social events. Further details can be obtained from the Society at Burlington House, London, W.1.

\section{Colonial Service: Recent Appointments}

THE following appointments have recently been made in the Colonial Service: A. G. Dalgleish (assistant secretary, Office of Member for Agriculture, Kenya), secretary for agriculture and natural resources (general), Kenya; R. F. A. L. Reed (senior agricultural officer, Nigeria), principal of schools, Agricultural Department, Western Region, Nigeria; E. Collins (chemist, Hong Kong), government chemist, Medical Department, Hong Kong; D. A. Frye (senior chemist, Federation of Malay\&), chief chemist, Singæpore ; J. W. Du Preez (senior geologist, Geological Survey Department, Nigeria), assistant director, Geological Survey Department, Nigeria; R. Walls (assistant director, Geological Survey Department, Nigeria), deputy director, Geological Survey Department, Nigeria; C. F. F. Gayle (agricultural officer, Jamaica), senior soil conservation officer, Jamaica ; J. H. Haughton (senior agricultural officer, Jamaica), chief agricultural officer (agronomy), Jamaica ; E. R. H. Martin (assistant agricultural superintendent, Antigua), agricultural superintendent, Antigua ; W. G. Stuart (senior agricultural officer, Jamaica), chief agricultural officer (development), Jamaica; A. D. Swan (meteorologist, Gold Coast), assistant director of observatory, Mauritius; A. K. Auckland, botanist (plant breeder), Tanganyika; T. E. Cobb, agricultural officer, Singapore; M. C. Cronin, J. B. Finney and P. R. Mrcerimmon, agricultural. officers, Nigeria; K. M. L. Matthews, agricultural officer, Uganda; W. F. Van der Byl Morkel, agricultural officer, Northern Rhodesia; $H$. Affleck, scientific officer, Federation of Malaya; R. F. Barnes, scientific officer (plant pathologist), Jamaica ; P. S. Corbet, scientific officer, East Africa High Commission; C. C. Draper, medical research officer, grade 2, East Africa High Commission; M. J. Holden, scientific officer, Sierra Leone; A. W. Allen, soil scientist, Department of Agriculture, North Borneo ; E. W. Fowler, chemist/assayer, Northern Rhodesia; D. A. Livingstone, economist/statistician, Kenya ; J. Lucas, fisheries officer, East Africa High Commission; J. Stoneman, fisheries officer, Uganda ; G. C. Vickers, veterinary officer, Jamaica; R. A. Wood, chemist, Department of Agriculture, Nyasaland.

\section{The Night Sky in February}

New moon occurs on Feb. 3d. 15h. 55m., U.x., and full moon on Feb. 17d. 19h. 17m. The following conjunctions with the moon take place: Feb. 4d. 21h., Mercury $4^{\circ}$ S. ; Feb. 12d. 05h., Jupiter $4^{\circ}$ S.; Feb. 23d. 22h., Saturn $8^{\circ}$ N. ; Feb. 26d. 05h., Mars $4^{\circ} \mathrm{N}$. In addition to these conjunctions with the moon, Mars is in conjunction with Antares on Feb. 25d. 0h., Mars being $5 \cdot 4^{\circ} \mathrm{N}$. Mercury is an evening star, setting at $17 \mathrm{~h} .45 \mathrm{~m}$. and $18 \mathrm{~h}$. $50 \mathrm{~m}$. at the beginning and middle of the month, respectively; but towards the end of the month it sets about twenty minutes after sunset, when it will be invisible. Venus, an evening star, sets too soon after the sun to be favourably seen. Mars, a morning star, rises about $2 \mathrm{~h}$. $15 \mathrm{~m}$. throughout the month. At the beginning of the month it lies a little south of $\gamma$ Libræ, and at the end of the month a little north of $\alpha$ Scorpii (it has already been pointed out that it is in conjunction with this star on Feb. 25). Jupiter, visible throughout the night, sets at $4 \mathrm{~h} .20 \mathrm{~m}$., $3 \mathrm{~h} .30 \mathrm{~m}$. and 2h. $35 \mathrm{~m}$. on February 1, 14 and 28, respectively, and is a conspicuous object (stellar magnitude about -2 ) west of $\zeta$ Tauri. Saturn rises at $0 \mathrm{~h} .50 \mathrm{~m}$., $0 \mathrm{~h}$. 